\title{
ETIKA POLITIK DALAM ISLAM (KONSTRUKSI DAN PERSFEKTIF)
}

\section{POLITICAL ETHICS IN ISLAM \\ (CONSTRUCTION AND PERSFECTIVE)}

\author{
Dewi Dahlan \\ Institut Agama Islam Negeri Batusangkar \\ Email: dewidahlan@iainbatusangkar.ac.id
}

\begin{abstract}
ABSTRAK: Etika dalam Islam dipandang sebagai bagian dari ibadah sehingga harus dilakukan berdasarkan prinsip-prinsip ibadah. Ada dua alasan pentingnya etika dalam islam. Pertama politik dipandang sebagai bagian dari ibadah sehingga harus dilakukan berdasarkan prinsip-prinsip ibadah. Misalnya dalam berpolitik harus diniatka LillahiTa'ala. Kedua, etika politik diandang sangat perlu dalam islam karena politik itu berkenaan dengan prinsip islam dalam pengelolaan masyarakat. Berpolitik sering menyangkut hubungan antar manusia, misalnya saling menghormati, menghargai, saling menghargai hak orang lain, saling menerima, dan tidak memaksakan pendapat sendiri. Itulah prinsip-prinsip hubungan antar manusia yang harus berlaku di dalam dunia politik.Kajian tentang hal ini belum merata diketahui oleh semua umat. Hal ini menjadi menarik, karena aturan tentang Etika (Etika Politik Islam) ini masih tetap dalam pembicaraan oleh pakar muslim. Tulisan ini mengemukakan bagaimana eksistensi etika berpolitik dalam pandangan islam. Untuk tulisan ini penulis melakukan penelitian kepada beberapa literature tentang politik secara umum mengenai Etika Politik Islam kemudian membandingkannya satu sama lain. Kemudian penulis melihat kepada prinsip-prinsip ajaran Islam secara umum dan dihubungkan kepada ajaran Islam tentang etika dengan segala ruang lingkupnya. Dari sini difahami bahwa etika politik islam merupakan kajian yang masih belum final dan berpeluang untuk terus menerus dikaji.
\end{abstract}

Keywords: Etika, Islam dan Etika Politik Islam

ABSTRACT:Ethics in Islam is seen as part of worship so that it must be done based on the principles of worship. There are two reasons for the importance of ethics in Islam. First, politics is seen as part of worship so that it must be done based on the principles of worship. For example, in politics you have to diniatka LillahiTa'ala. Second, political ethics is considered very necessary in Islam because politics is related to Islamic principles in community management. Politics is often about human relations, for example mutual respect, respect, mutual respect for the rights of others, mutual acceptance, and does not impose one's own opinion. Those are the principles of human relations that must apply in the world of politics. The study of this matter is not evenly known by all people. This becomes interesting, because the rules on Ethics (Islamic Political Ethics) are still being discussed by Muslim experts. This paper suggests how the existence of political ethics in the view of Islam. For this paper the author conducted research on several literatures on politics in general regarding Islamic Political Ethics and then compared them with one another. Then the author looks at the principles of Islamic teachings in general and is linked to Islamic teachings on ethics in all their scope. From this it is understood that Islamic political ethics is a study that is still not final and has the opportunity to be continuously studied.

Keywords: Ethics, Islam and Islamic Political Ethics

\section{A. PENDAHULUAN}

Etika Islam mencakup segala aspek kehidupan manusia, menjelaskan dan mengatur hubungan manusia dengan Allah dan hubungan manusia dengan sesamanya serta dengan alam lingkungan. Etika politik mengandung tiga tuntutan yaitu pertama upaya hidup baik bersama dan untuk orang lain, kedua upaya memperluas lingkup kebebasan, ketiga untuk membangun institusi-institusi yang adil. Hidup baik bersama dan untuk orang lain tidak mungkin terwujud, kecuali apabila menerima 
pluralitas dan dalam kerangka institusi-institusi yang adil. Hidup baik tidak lain adalah cita-cita kebebasan. Kesempurnaan eksistensi atau pencapaian keutamaan. Institusi-institusi yang adil memungkinkan perwujudan kebebasan dengan menghindarkan warga negara atau kelompok-kelompok dari saling merugikan. Sebaliknya, kebebasan warga negara mendorong inisiatif dan sikap kritis terhadap institusi-institusi yang tidak adil. Etika politik tidak hanya menyangkut perilaku individual saja, tetapi terkait dengan tindakan kolektif (etika sosial).

Dalam etika individual, orang yang mempunyai pandangan tertentu dapat langsung mewujudkannya dalam tindakan. Adapun dalam etika politik, sebagai etika sosial, untuk mewujudkan pandangan dibutuhkan persetujuan dari sebanyak mungkin warga negara karena menyangkut tindakan kolektif. Hubungan antara pandangan hidup seseorang dan tindakan kolektif tidak langsung membutuhkan perantara. Perantara ini berfungsi menjembatani pandangan pribadi dengan tindakan kolektif, dan dapat pula berupa simbol-simbol ataupun nilai-nilai seperti agama, demokrasi, dan keadilan, kebebasan, kesetaraan, dan sebagainya. Melalui simbol dan nilai itu, politikus berusaha meyakinkan sebanyak mungkin warga negara agar menerima pandangannya sehingga mendorong tindakan bersama. Politik disebut seni karena membutuhkan kemampuan untuk meyakinkan melalui wicara dan persuasi, bukan manipulasi, kebohongan, pengkhianatan dan kekerasan. Etika politik kritis terhadap manipulasi atau penyalahgunaan nilai dan simbol-simbol itu. Ia berkaitan dengan masalah struktur sosial, politik, ekonomi, dan budaya yang mengondisikan tindakan kolektif.

Pada tingkat ini, etika politik dipahami sebagai perwujudan sikap dan perilaku politikus atau warga negara. Politikus yang baik adalah jujur, santun memiliki integritas, menghargai orang lain, menerima pluralitas, memiliki keprihatinan untuk kesejahteraan umum dan tidak mementingkan golongannya. Jadi, politikus yang menjalankan etika politik adalah negawaran yang mempunyai keutamaan-keutamaan moral

Dalam sejarah filsafat politik, filsuf seperti Socrtates sering diangkat sebagai model yang memiliki kejujuran dan integritas. Politik dimengerri sebagai seni yang mengandung kesantunan. Kesantunan politik, diukur dari keutamaan moral. Hal ini tampak bila ada pengakuan timbal balik dan hubungan fair diantara para pelaku. Pemahaman etika politik macam ini belum cukup karena sudah puas bila diidentikkan dengan kualitas moral politikus. Belum mencukupi karena tidak berbeda dengan pernyataan. "Bila setiap politkus jujur maka Indonesia akan makmur"

Secara kohorensif, pernyataan ini sahih, tidak terbantahkan, tetapi dari secara korespondensif, hipotesis itu jauh dari kenyataan (realis). Etika politik, yang hanya puas dengan koherensi norma-normanyadan tidak memperhitungkan relitas politik, cenderung mandul. Akan tetapi bukankah real politik, seperti dikatakan Machiavell, adalah hubungan kekuasaan atau pertarungan kekuatan? Masyarakat tidak terdiri atas individu-individu subjek hukum, tetapi terdiri atas kelompok-kelompok yang mempunyai kepentingan yang saling berlawanan. Politik yang baik adalah politik yang dapat mencapai tujuannya, apapun caranya.

Relevansi etika politik terletak pada kemampuannya untuk melunakkan kekuatan it dan mengatur kepentingan-kepentingan kelompok dengan membangun institusi-institusi yang lebih adil. Beberapa prinsip ajaran islam yang dapat dijadikan etika dalam kehidupan berbangsa dan bernegara saat ini, antara lain, meliputi kekuasaan sebagai amanah, musyawarah, prinsip keadilan sosial, prinsip persamaan, pengakuan dan perlindungan, terhadap hak-hak asasi manusia, prinsip peradilan bebas, prinsip perdamaian dan keselamatan, prinsip kesejahteraan, prinsip ketaatan rakyat.

\section{B. METODE}

Untuk tulisan ini penulis melakukan penelitian kepada beberapa literature tentang Politik secara umum mengenai Etika Politik Islam kemudian membandingkannya satu sama lain. Kemudian penulis melihat kepada prinsip-prinsip ajaran Islam secara umum dan dihubungkan kepada ajaran Islam tentang etika dengan segala ruang lingkupnya. Dari sini difahami bahwa etika politik islam merupakan kajian yang masih belum final dan berpeluang untuk terus menerus dikaji. 


\section{HASIL BAHASAN}

\section{Kajian Etika Politik dan Kegunaannya}

Dalam dunia perpolitikan, Etika yang baik sangatlah diperlukan. Untuk menjalankan sutau alur politik Etika yang sesuai sangatlah penting, karena dari suatu proses untuk menjalankan suatu tugas atau mandat, sesuai dengan norma dan aturan akan mendapatkan suatu hasil yang diinginkan secara maksimal dan tujuan yang telah disepakati bersama. Karena dalam suatu kebijakan yang dikeluarkan oleh pemerintah bersumber dari kerja dari lembaga yang diberi kewenangan untuk membentuknya, yang mana etika baik juga berpengaruh terhadap kebijakan itu. Jadi hal-hal kecil dalam pelaksanaan dalam dunia politik harus diperhatikan guna menuju suatu keadilan sebagai manusia yang telah diberikan kewenangan dan kekuasaan.

Mulai dari pengertian Etika, secara etimologi kata "etika" berasal dari bahasa yunani yaitu "ethos" yang berarti watak. Etika pada dasarnya sudah terbentu budaya-budaya dan kebiasaan dalam melakukan kegiatan sehari-hari. Dengan dilakukannya secara berulang-ulang maka terbentuklah etika sesorang yang terbentuk pada sifat pribadinya dan lama-lama menjadi watak.

Menurut Franz magnes suseno (1988: 2) EtikaPolitik memberikan patokan-patokan, orientasi dan pegangan normatif bagi mereka yang memang ingin menilai kualitas tatanan dan keidupan politik dengan tolok ukur martabat manusia. Dalam beretika tolak ukur untuk menimbang suatu etika berdasarkan martabat manusia sebagai pendorong terwujudnya etika yang sesuai dengan lingkunganmasyarakat. Serta sifat saling menguntungkan untuk mewujudkan politk yang baik, agar sikap salng percaya dapat terwujud guna mewujudkan kesejahteraan masyarakat.

Dalam pengertian etikapolitik di atas adalah suatu dasar-dasar dan patokan untuk melaksanakan suatu proses politik dalam menjalankan tugas atau kewenangan dan sebagai batasan perilaku. Dapat diartikan batasan dalam beretika, memiliki fungsi pengendali agar perilaku manusia tidak keluar dari konteks yang dianggap sebagai suatu batasan. Yang mana batasan tersebut harus dipatuhi serta dijaga agar perilaku tidak melewati batasnya. Pada dasarnya batasan tersebut berasal dari norma dan nilai yang diyakini kebenarannya dan beradap terhadap lingkungan sekitar. Dalam melaksanakan etika politik tidak lepas dari tolok ukur terhadap menjunjung tinggi nilai kemanusiaan dan martabat manusia.

Dalam konteks negara Indonesia etikapolitik juga bersumber dari dasar Negara, yaitu Pancasila. Fungsi Pancasila sebagai dasar Negara juga sebagai pedoman bangsa Indonesia dalam menjalankan suatu kegiatan entah itu untuk melaksanakan proses ketatanegaran dan dasar pembuatan undang-undang atau kebijakan serta pedoman bagi masyarakat dalam berperilaku berdasarkan nilai-nilai sosial yang adil dan beradap. Berpegang teguh terhapap agama yang diyakininya. Serta ajaran etika pada seorang pemimpin untuk dapat menjadi seorang pemimpin yang hitmat, bijaksana dalam permusyawaratan perwakilan.

Dalam menjalankan etika poltik pada dasarnya seorang pejabat memiliki kebebasan dalam berperilaku guna mewujudkan seni dan kreatifitas dalam menjalankan suatu kekuasaannya. Hal ini berkaitan dengan arti politik yang ada. Yaitu politik adalah suatu seni untuk meraih kekuasaan dalam buku Miriam Budiardjo. Akan tetapi kebebasan itu harus pula berdasarkan kesusilaan etika. Menurut Isjwara (1980:89) untuk itu mengatur kehidupan politik, dengan jalan menjadikan kesusilaan etika sebagai dasar politik dapat diharapkan adanya politik yang mengindahkan aturan-aturan permainan, apa yang harus dilakukan dan apa yang wajib dibiarkan.

Kajian etika politik bermuara pada pembahasan prinsip-prinsip moralitas politik, terkait dengan norma-norma penyelenggaraan kenegaraan. Menurut Hegel, kajian semacam ini berguna untuk mengonstruksikan negara sebagaimana seharusnya. Fungsi etika politik terbatas sebagai alat teoritis untuk menguji dan mempertanyakan legitimasi politik secara bertanggung jawab. Dalam arti, tidak menggunakan ukuran emosi, prasangka, dan apriori, tetapi menggunakan standar metodologi ilmiah, secara rasional, objektif, dan argumentatif.

Tugas etika politik bersifat subsidair. Dalam hal ini, membantu agar pembahasan masalah ideologi dijalankan secara objektif melalui argumen-argumen yang dapat dipahami oleh semua orang yang mengerti masalah. Etika politik memberi patokan dan norma penilaian mutu politik dan penyelenggaraan negaradengan tolok ukur martabat manusia. Etika politik tidak memberi 
manfaat praksis dan tidak memberi arahan secar subjektif kepada para praktisi politik atau penyelenggara negara.

Etika politik, justru bermanfaat untuk menuntut pertanggungjawaban berbagai klaim politik atas dasar prinsip-prinsip moral. Etika politik tidak mengklaim politik sebab klaim tersebut justru harus didasarkan atas pembenaran legitimasi yang benar, tidak semata-ma ideologis. Bahkan etika politik dapat berfungsi sebagai kritik ideologi. Oleh karena itu, sumbangan etika politik pada pembangunan adalah penegakan komitmen pada pencarian kebenaran legitimasi politik, baik secara kognitif maupun normatif.

Etika politik tidak memiliki kewenangan untuk menawarkan suatus sistem moral individu, sikap moral, ataupun suatu norma sebagai dasar negara. Dalam arti tidak mengembangkan prinsip-prinsip moral politik secara mengawang-awang dan hanya mengandalkan rasionalitas semata. Akan tetapi, etika berangkat dari realitas terutama pada tataran realitas yang telah dikaji berdasarkan ilmu politik. Etika politik memberi argumentasi lebih lanjut tentang berbagai konsep yang tealah dirumuskan ilmu politik.

Sebagaimana etika, sebagai bagian dari filsafat, etika politik mempelajari realitas, misalnya sistem moral, namun tidak dapat, menjadi sistem moral itu sendiri. Perlu digarisbawahi bahwasanya etika politik membantu mengejawantahkan sistem moral atau ideologi negara yang luhur ke dalam reliatas politik. Misalnya bagaimana pertanggungjwaban, dasar-dasar etik kerakyatan yang dipimpin hikmah kebijaksanaan dalam permusyawaratan perwakilan.

Agak berbeda dengan hal itu, kita juga ingin melihat watak, karakter atau ciri dari etika politik islam. Dalam islam, etika politik identik dengan akhlak siyasy. Akan tetapi, sebagian ahli, membedakan antara konsep akhlak dengan etika. Etika tetap dipandang produk pemikiran yang memiliki kebenaran relatif (zdhonny), diangkat dari filsafat, dan bersifat rasional (ta'aquli). konsep akhlak cenderung (tanaquli) dan (Tasyri'iy), banyak dibangun atas dasar dalil qath'I yang implikasi kebenarannyapun relatif qatth'I. Konsep akhlak selalu merujuk pada idealitas tatanan kehidupan yang baik dan benar. Yang bersumber pada Alqur'an dan hadis nabi.

Implementasi nilai etika dan moral dalam islam merupakan suatu keharusan, tak terkecuali dalam penyelenggaraan negara, sebab Rasulullah mendirikan negara Madinah, berdasarkan nilai akhlak karimah yang mesti diteladani oleh setiap orang muslim. Dalam islam, kajian etika, politik bukan semata-mata untuk kepentingan ilmu dan kepentingan kritik ideologi, bukan pula merupakan bagian dari filsafat, melainkan merupakan bagian integral dari syariat, yang wajib diamalkan oleh setiap muslim dalam kehidupan, lebih-lebih dalam lapangan politik dan penyelenggaraan kenegaraan.

Etika politik termasuk dalam kelompok etika sosial yakni yang membahas norma-norma moral yang seharusnya menimbulkan sikap dan tindakan antar manusia, karena hampir semua kewajiban manusia bergandengan dengan kenyataan bahwa ia merupakan makhluk sosial. Etika politik tidak menawarkan suatu sistem normatif sebagai dasar negara. Etika bersifat reflektif yakni memberikan sumbangan pemikiran tentang bagaimana masalah-masalah kehidupn dapat dihadapi,tetapi tidak menawarkan tentang bagaimana cara memecahkannya. Dengan demikian etik politik mempertanyakan tanggung jawab dan kewajiban manusia sebagai manusia dan bukan sebagai warga negara terhadap negara, terhadap hukum yang berlaku dan lain sebagainya. Karena kebaikan manusia sebagai manusia dan kebaikan manusia sebagai warga negra tidak identik.

Fungsi etika politik terbatas pada penyediaan pemikiran pemikiran teoritis untuk mempertanyakan dan menjelaskan legitimasi politik secara bertanggung jawab, rasional, objektif dan argumentatif. oleh karena itu tugas etika politik subsider dalam arti membantu agar pembahasan masalah-masalah ideologi dapat dijalankan dengan objektif artinya berdasarkan argumen-argumen yang dapat dipahami dan ditanggapioleh semua pihak yang mengerti permasalahan. Selain itu etika politik dapat berfungsi sebagai sarana kritik ideologi (bukan negara dan hukum) berupa paham paham dan strategi legitimasi yang mendasari penyelenggaraan negara. Jadi etika politik hanya dapat membantu usaha masyarakat untuk mengejawantahkan ideologi negara yang luhur ke dalam realitas politik yang nyata. Misalnya, dengan merefleksikan inti/ hakikat keadilan sosial, bagaimana kekuasan harus ditangani agar sesuai dengan martabat 
manusia.Sejak Aristoteles para filosuf telah merenungkan manusia sebagai makhluk politik (zoon politicon), makhluk komunitas Nietzche, Max Weber dan Hans Monrgenthau barangkali adalah orang orang pertma yang memahami sebutan makhluk politik (secara esensial) dalam term lain adalah makhluk yang mencari kekuasaan. Dan jika kita ingin mencari dan membahas konsep kekuasaan maka kita tidak dapat terlepas dari penilaian atas kekuasaan di dalam politik yang selalu bergantung secara fundamental pada pandangan tertentu tentang manusia.

Bagi orang (siapapun) yang brsikap seperti kaum optimis masa pencerahan dan kaum liberalis naif, maka bisa dipastikan bahwa mereka memandang makhluk manusia pada dasarnya adalah baik, rasional, mampu belajar dan dilatih dan dunia dianggapnya sebagai kosmos yang teratur. Ia melihat politik sebagai alat untuk kemajuan manusia, juga latat untuk memperbaiki dunia kekuasaan, kemudian diartikan yang baik dan berguna. Walaupun pengertian ini kemudian banyak menimbulkan pertanyaan, salah satunya adalah: Tidak dapatkah kejahatan muncul dari apa yang baikdan memiliki tujuan baik?.Sementara bagi orang (siapapun) yang memiliki pandangan seperti kaum analis pesimis dan kritikus ideologis yang berlatar belakang filosofis atau teologis, maka pasti akan memandang makhluk manusia bersifat korup, irrasional dan berbahaya. Kemudian dunia dipersepsikan pada dasarnya kacau dan politik selalu dilihat sebagai urusan yang kotor, aktivitas immoral yang tak terhindarkan. Pada intinya kekuasaan dipandang sebagai sesuatu yang jahat dan kejam. Tetapi itupun masih menimbukan pertanyaan: Apakah setiap pengguna kekuasaan politik adalah jelek dan setiap tindakan yang tak terhindarkan adalah jelek?Lain lagi, bila dilihat dari perspektif seorang realis sejati, dimana dunia dilihatnya sebagai sebuah realitas yang terpecah atau terbelah. Jika pada dasarnya manusia adalah jahat, maka tak mungkin ada pemerintah. Kemudian, jika semua manusia adalah baik, maka tak perlu ada pemerintahan. Jadi harus diakui bahwa manusia sejati adalah makhluk yang kompleks dan ambivalen, berada di tengah-tengah antara jalan akal budi dan tak berakal budi, antara baik dan jahat, campuran antara egoisme dan kebaikan.

Secara umum, kekuasaan adalah kompetensi, kemungkinan atau kebebasan untuk menentukan sesuatu, orang atau lingkungan lain. Atau menurut definisi sosiolog klasik Max Weber, kekuasaan adalah setiap kesempatan untuk menetapkan kehendak diri sendiri dalam sebuah hubungan sosial meskipun dihadapkan pada sebuah perlawanan, tak masalah apapun basis kesempatan itu. Dengan demikian setiap sifat orang dapat dipahami dan setiap konstelasi dapat pula dipahami. Dengan asumsi ini akan mudah mengarahkan dan memposisikan seseorang sesuai dengan ketetapan kehendaknya sendiri dalam situasi tertentu (Winkelman, 1972: 28).Dengan demikian kekuasaan dan kekuasaan politik dalam arti luas, sebenarnya adalah sebagai ungkapan sifat dasar manusia yang kedua-duanya sama mengalami ambivalensi: Artinya, di satu sisi kekuasaan manusia dapat digunakan untuk kebaikan, dengana cara yang betul betul yang manusiawi, baik untuk kemakmuran mereka yang berkepentingan, untuk mereka yng berada di sekitar kekuasaan tersebut dan lingkungannyaa. Kemudian di sisi lain kekuasaan manusiabisa juga digunakan untuk kejahatan, melalui cara yang tidak manusiawi dan tidaka mengenal prikemanusiaan, baik dengan sengajaa untuk merugikan mereka yang berkepentingan maupun untuk mereka yang ada di sekitarnya dan lingkungannya.

Kekuasaan yang tak berprikemanusiaan ini lebih sering muncul malah menjadi yang biasa.Untuk apa sebenarnya kekuasaan itu? Bertolak dari pemikiran Max Weber bahwa seseorang yang terlibat dalam politik, adalah mencari kekuasaan; kekuasaan sebagai alat untuk mencapai tujuan lain (ideal atau kepentingan sendiri) -Atau kekuasaan untuk kekuasaan itu sendiri. Atau untuk mendapatkan martabat yang diberikan oleh kekuasaan itu sendiri (Hans Kung, 2002: 132). .Seharusnyalah kekuasaan dicari tidak hanya untuk kepentingan sendiri tetapi sebagai alat untukmelayani tujuan manusia. Kekuasaan politik dapat dan harus direlaativiskan untuk kepentingan rakyat. Di segala tingkatan politik, kekuasaan harus dipakai untuk melayani, bukan untuk mendominasi, apapun komitmen pribadinya. Kekuasaan dan dominasi sama sekali tidak identik.

Di segala tingkatan politik, apabila orang dapat melihat secara terus menerus bahwa seorang politisi, kelompok politisi atau pemeintah menggunakan kekuasaan sebagai alat untuk 
mendominasi bukan untuk melayani, maka kekuasaaan akan mendominasi pemikiran dan tindakan politik, sertaa akan menimbulkan kebencian dan permusuhan; sungguh, kekuasaan akan mengakibatkan peperangan, dingin atau panas. Tetapi dimana politisi atau kelompok tertentu atau sebuah pemerintah berusaha untuk melihat bahwa kekuasaan adalah untuk melayani, bukan untuk mendominasi, maka dalam perjuangan kekuasaan mereka membantu memanusiakan persaingan yang mematikan dan mempromosikan penghormatan dan penghargaan pada orang lain, mediasi, pengertian dan perdamaian (Hans Kung, 2002:134). Berdasarkan pemikiran tersebut, etika menjadi tantangan bagi politisi, perlunya etika politik sebagai pengendalian kekuasaaan politik dan penyalahgunaan kekuasaan oleh institusi sebagai masalah fundamental dari teori-teori negara

\section{Akhlak Politik (Akhlak Siyasy)}

Islam mempunyai dua sumber, yaitu Alqur'an dan AsSunnah yang menjadi pegangan dalam menentukan segala urusan dunia dan akhirat. Kedua sumber ini sekaligus menjadi sumber akhak islamiah. Prinsip-prinsip dan kaidah ilmu akhlak islam, semuanya berlandaskan pada wahyu yang bersifat mutlak. Dengan kata lain, akhlak ialah suatu sistem yang menilai perbuatan zahir dan batin manusia, baik secara individual maupun sosial dalam berinteraksi.

Dalam kitabnya Tahdzib Al- Akhlakk, Ibn Miskawaih membahas etika secara sistematis ke dalam beberapa tema sentral, yakni: jiwa, kebaikan dan kebahagiaan, keadilan, cinta dan persahabatan serta penyakit dan pengobatan jiwa. Pembahasan ini dimaksudkan untuk pendidikan dan pengajaran tentang potensi jiwa manusia.

Dalam hidup ini ada dua nilai yang menentukan perbuatan manusia, yaitu nilai baik dan nilai buruk (good and bad), betul dan salah (true and false). penilaian ini berlaku dalam semua lapangan kehidupan manusia. Apakah yang dimaksudkan dengan baik dan buruk, betul dan salah, benar dan palsu itu? Persoalan-persoalan inilah yang akan dijawab oleh ilmu akhlak.

Kebutuhan hidup manusia berbeda antara individu-individu lain. Ada yang menjadikan kebendaan sebagai kebutuhan yang diburu dalam kehidupan. Ada yang menjadikan kebesaran ataupun kekuasaan dan ada pula yang mencari popularitas. Ada yang berusaha mencari ilmu pengetahuan, dan ada pula golongan yang memandang kehidupan dunia dengan bersifat zuhud, hidup seerhana.

Perbedaan pandangan inilah yang menyebabkan timbulnya beberapa aliran di dalam memahami akhlak. Semua pandangan ini, apabila diteliti dengan seksama, tidak dapat dijadikan sebagai kesimpulan akhir atau tertinggi yang mesti dicapai manusia. Oleh karena itu, perbedaan itu, ada satu kebutuhan hakiki yang wajib dituntut oleh manusia. Apabila perilaku atau perbuatan manusia itu selaras dan berimbang, ia jauh dari keburukan.

Persoalan-persoalan inilah yang menjadi wilayah kajian ilmu akhlak, yaitu ilmu yang menerangkanbaik serta buruk, dan menerangkan sesuatu yang sepatutnya dilakukan oleh seseorang dalam perjalanan hidupnya di dunia ini. Ilmu inijuga berusaha menerangkan apa yang seharusnya dituju oleh manusia dan menggariskan jalan-jalan yang mesti dilaluinya untuk melaksanakan sesuatu dalam hidup ini.

Akhlak berfungsi untuk mengkaji dan meneliti aspek perilaku dan perbuatan manusia. Akhlak menilai dari segi baik atau buruknya perbuatan itu, apa yang patut dan apa yang tidak patut dilakukan seeorang. Segala tindakan manusia dilakukan ecara sadar dan dengan ikhtiar dalam berhubungan dengan Allah, sesama manusia, alam sekitar, hubungan dengan diri sendiri dan sebagainya, semuanya mengandung nilai akhlak. Segala tindakan manusia, baik yang berupa pribadi maupun bersifat sosial, ekonomi politik, kebudayaan, dan sebagainya mengandung nilai akhlak yang diambil dan dipertanggungjawabkan kepada mereka yang terlibat di dalamnya. Nilai akhlak yang buruk akan berakibat siksaaan. Para filsuf dan teolog sering membahas arti baik dan buruk serta pencipta kelakuan tersebut. Secara real, manusia berpotensi untuk berkelakukan baikataupun berkelakukan buruk.

Meskipun kedua potensi itu terdapat dalam jiwa manusia, Allah terlebih dahulu memberikan isyarat kepada manusia untuk menghiasi perilakunya dengan akhlak yang baik karena pada dasarnya, manusia cenderung pada kebaikan. Kecenderungan ini terbukti dari kesamaan 
konsep-konsep pokok moral dan etika paa setiap peradaban dan zaman. Perbedaannya hanya pada bentuk dan penerapannya atau pada pengertiannya. Dari seluruh peradaban, tidak terkecuali aspek politik, tidak ada yang menganggap baik terhadap kebohongan, penipuan, atau keangkuhan. Tidak ada manusia yang menilai bahwa pengelolaan negara yang baik adalah perilaku buruk, tidak pula ada orang yang menilai baik kepada para anggota legislatif atau pejabat birokrasi yang mengobral janji dalam kampanye, tetapi setelah duduk dikursi jabatan, ia tidak melaksanakan apa yang diucapkannya sebagai perilaku baik. Tidak akan ada yang menilai bahwa presiden yang hormat kepada orang tuanya adalah presiden yang tidak sopan dan berprilaku jahat. Kebaikan ini, dalam bahasa Alqur'an disebut dengan makruf, suatu konsep yang dapat diterima oleh berbagai kalangan umat manusia.

Dalam bidang politik, para filsuf sejak zaman Yunani kuno hingga pemikir kontemporer, baik dari kalangan muslim maupun nonmuslim, telah banyak mengupas akhlak atau sekurang-kurangnya etika yang dihubungkan dengan berbagai kekuasaan, kepemimpinan, pemerinthandan hasil rumusan mereka menjadi etika politik atau akhlaqus Siyasi.

Yusuf Qardawi mengatakan akhlak yang disebutkan dalam Alquran memiliki keistimewaan karena keumumannya, tanpa ada pemilahan antara satu bangsa dan bangsa lain, antara satu golongan dengan golongan lain. Akhlak memiliki keistimewaan karena keseimbangannya, yaitu memberikan hak kepada akal, kepada hati dan badan, sebagaimana ia memberikan hak kepada individu dan masyarakat sehingga seseorang tidak berbuat zalimterhadap orang lain.

Tentang kecenderungan manusa berbuat baik, disinyalir oleh Nabi SAW dalam hadis riwayat Imam Al Bukhari, “ Setiap anak dilahirkan dalam keadaan suci (fithrah) hanya kedua orang tuanya atau lingkungannya menjadikan dia (Yahudi), Nasrani atau Majusi.

Tolok ukur perbuatan baik dan buruk harus merujuk pada ketentuan Allah. Apa yang dinilai baik oleh Allah, pasti baik dalam esensinya. Tidak mungkin kebohongan dinilai sebagai kelakuan baik, karena esensi kebohongn adalah keburukan. Rasulullah SAW selalu memerintahkan umatnya agar sekuat mungkin meneladani sifat-sifat Allah. "berakhlaklah dengan akhlak Allah". sementara ketika Aisyah ditanya tentang akhlak Nabi SAW. Ia menjawab. "Budi pekerti Nabi SAW adalah Alqur'an.

Meneladani sifat-sifat Allah, baik sifat kelembutan-Nya maupun sifat agung-Nya adalah keseimbangan akhlak proporsional. Ketika seorang muslim berusaha meneladani kekuasaan dan kebesaran Allah, harus diingat bahwa sebagai makhluk, manusia terdiri atas jasad dan roh yang kedua-duanya harus berjalan sama-sama kuat. Kekuatan dan kebesaran harus diarahkan untuk menolong yang lemah bukan untuk menopang yang salah atau yang sewenang-wenang. Oleh karena itu, dalam memegang amanah kepemimpinan dan pelaksanaan pemerintahan, akhlak harus dijadikan pedoman dan melekat dalam implementasinya, serta terus menerus dievaluasi pada setiap saat oleh seluruh manusia, baik individu maupun masyarakat. Dalam arti para pelaku politik dan birokrat pemerintah harus menerapkan prinsip-prinsip akhlaqi pada perilaku administrasi, manajemen kepemimpinan, dan keorganisasian. Akhlak memiliki makna yang luas dari sekadar etika, meskipun keduanya sama-sama memperhatikan kelakukan manusia menuju kesempurnaan dan kesucian hidup. Etika terbatas pada tingkah laku lahiriah, salah satu segi penjelmaan hidup kemasyarakatan, timbul dari dan dalam masyarakat, bersifat relatif, dan terikat pada ruang dan waktu. Adapun akhlak berkaitan dengan suasana batin ataupun pikiran. Akhlak bersumber kepada ajaran Alqur'an dan sunnah Rasulullah SAW. Ukuran baik dan buruk bersifat absolut, berlaku untuk seluruh masa dan tempat, sedangkan etika hanyalah produk kebudayaan yang dapat berlainan menurut masyarakat yang melahirkannya. Etika dapat berbeda-beda menurut perbedaan manusia dan zamannya. Akhlak mencakup berbagai aspek kehidupan mulai dari akhlak terhadap Allah, hingga kepada sesama makhluk: manusia, binatang, tumbuh-tumbuhan hingga benda-benda tak bernyawa seperti lingkungan alam.

Akhlak terhadap Allah dimulai dari meyakini, menyucikan membesarkan menaati perintah, menjauhi larangan, hingga berserah diri kepada-Nya. Tidak sedikit ayat yang memerintahkan manusia untuk menjadikan Allah sebagai "wakil" atau pelindung. Apabila seseorang mewakilkan kepada orang lain tentang suatu perbuatan, yang mewakili 
itu telah menjadi dirinya, sehingga sang wakil harus melaksanakan kehendak yang diwakilinya. Menjadikan Allah sebagai wakil adalah menyerahkan segala urusan kepada-Nya. Dialah yang berkehendak dan bertindak sesuai dengan kehendak manusia yang menyerahkan urusan manusia. Allah maha pengasih dan penyayang (Rahman dan Rahim). keda sifat tersebut dapat dinisbahkan kepaa manusia, walaupun hakikatnya tidak sama dengan rahman dan rahim manusia, karena manusia memiliki keterbatasan. Oleh karena itu akhlak dan etika kepada Allah adalah landasan etika atau akhlak terhadap sesama manusia ataupun alam. Kebaikan kepada Allah hendaknya terefleksikan menjadi kebaikan terhadap manusia dan alam. Dengan demikian, menyelenggarakan negara dan pemerintahan tidak bisa dipisahkan dari akhlak peda Allah karean tugas publik ini dalam islam dipandang sebagai bagian dari misi aplikasi ajaran dan syariat islam.

\section{PENUTUP}

Etika Politik Islam relatif berbeda dengan etika politik umum sebab etika politik islam memiliki dasar yang sakral dari wahyu Tuhan dan sunnah Rasul. Interpretasi yang bersifat deduktif dari nash Al-Qur'an dan Sunnah Rasul menjadi suatu yang niscaya. Demikian pula sebaliknya, ketika realitas sosial muncul, legitimasi atas realitas itupun harus jelas dalam etika politik islam. Artinya realitas yang baik dapat diberi justifikasi sebagai sesuatu yang patut dipertahankan jika sesuai dengan spirit nash tersebut, meskipun hasil aktualisasinya tidak memiliki nilai indoktrinasi. Oleh karena itu, epistemologi akhlak tidak terlepas dari metode-metode pemahaman atas ajaran (istinbath, istidhlal, dan ijtihad). terutama dalam konteks penerapan etika politik, hampir seluruh jalur pengambilan keputusan dalam syariat islam dapat diperlakukan secara proporsional.

Dengan demikian, etika politik bertolak dari masalah-masalah di bidang politik yang memerlukan penanganan etis. Etika politik tidak dimulai dari ruang kosong. Realitas politik selalu merupakan bidang yang dipertanyakan dan diperebutkan secara ideologis. Metode etika politik atas dasar realitas ini dikenal dengan metode kritis-negatif. Kritis karena tidak dimulai dari pendapat sendiri, tetapi berangkat dari teori-teori atau pahamm-paham yang relevan, kemudian diperiksa secara kritis, dengan cara memisahkan unsur-unsur yang dinilai tepat diantara yang tidak tepat. Negatif, karena tidak dimulai dari penetapan prinsip-prinsip tertentu, melainkan membongkar pandangan-pandangan moral politik yang ada, membuang yang tidak tahan uji, tetapi mempertahankan apa yang semestinya sebagai prinsip.

\section{E.DAFTAR PUSTAKA}

A. Mustari Pide, Pengantar Hukum Tata Negarai. Cet. III; Jakarta: Gaya Media Pratama, 1999.

Abd. Muin Salim, Konsepsi Kekuasaan Politik Dalam Al-Qur`an . Cet. II; Jakarta: RajaGrafindo Persada, 1995.

Ahmad Syafii Maarif, Islam dan Masalah Kenegaraan: Studi tentang Pencaturan dalam Konstituante. Cet. I; Jakarta: LP3ES, 1985.

Ashadi L Diab. 2016. Hukum Islam dan Ketatanegaraan. Jurnal Al-'Adl, Vol. 9, No. 2, (https://ejournal.iainkendari.ac.id, diakses 20 November 2018).

Al-Maududi, Khalifah dan Kerajaan, diterjemahkan oleh Muhammad al-Baqir. Bandung: Mizan, 1984.

Abdul Halim. 2013. Membangun Teori Politik Hukum Islam di Indonesia. Jurnal Ahkam, Vol. XIII, No. 2, (https://journal.uinjkt.ac.id, diakses 20 November 2018).

Abdul Rahman. 2016. Hukum Islam dalam Konstitusi Sebuah Harapan Masa Depan. Jurnal RIHLAH Jurnal Sejarah dan Kebudayaan, Vol. 4 No 1, (https://journal.uin-alauddin.ac.id/index.php, diakses 20 November 2018).

Departemen Agama RI, Al-Qur`an dan Terjemahnya Semarang: Toha Putra, 1988. 
Francois Venter. 2012. South Africa: A Diceyan Rechtstaat?(2012) 57:4 Mc Gill Law Journal Revue De Droit De Mc Gill.

Ibnu Kencana Syafi'i, Hukum Tata Negara. Cet. I; Jakarta: Dunia Pustaka Raya, 1991.

Ibnu Rochman, Hukum Islam dalam Prespektif, Yogyakarta: Philosophi Press, 2001

I Gede Sujana. 2016. Eksistensi Politik Hukum Perundang-Undangan dalam Sistem Ketatanegaraan Republik Indonesia. Jurnal Kajian Pendidikan Widya Accarya FKIP Universitas Dwijendra ISSN No. 2085-0018, (https://ejournal.undwi.ac.id, diakses 20 November 2018).

Hariantati, Runi. Etika Politik. DEMOKRASIVol.IINo.1Th. 2003.

Martin Krygier.Rule Of Law(and Rechtsstaat). International Encyclopedia Of The Social And Behavioral Sciences, Second Edition.2015, 780-787.

Mohammad S. el-Awa, Sistem Politik dalam Pemerintahan Islam. Surabaya: Bina Ilmu, 1983.

Muhammad Tahir Azhary, Negara Hukum: Suatu Studi Tentang Prinsip-Prinsipnya Dilhat dari Segi Hukum Islam, Implementasinya pada Periode Negara Masinah dan Masa Kini. Cet. I; Jakarta: Bulan Bintang, 1992.

Munawir Sjadzali, Islam dan Tata Negara: ajaran, sejarah dan pemikiran Cet. V; Jakarta: UI-Press, 1993.

Ma'mun Mu'min. 2014. Pemikiran Hukum Tata Negara Fazlur Rahman. Jurnal YUDISIA, Vol. 5, No. 2, (http://download.portalgaruda.org/article.php, diakses 20 November 2018).

Rashda Diana. 2017. Al-Mawardi dan Konsep Kenegaraan dalam Islam. Jurnal TSAQAFAH, Vol. 13 No. 1, (http://https://www.researchgate.net/publication/318746504, diakses 20 November 2018).

Rr Rina Antasari. 2015. Hukum Islam dalam Ruang Sistem Hukum di Indonesia. Jurnal Istinbath/ No. 16/ Th. XIV, (https://jurnal.radenfatah.ac.id, diakses 20 November 2018).

Sarip. 2018. Pemikiran The King Can Do Not Wrong Dalam Politik Hukum Ketatanegaraan Indonesia. Kanun Jurnal Ilmu Hukum. Vol 20, No 2, (https://jurnal.unsyiah.ac.id, diakses 20 November 2018).

Salim.Abdul.Muin. 2002. Fiqh Siyasah Konsepsi Kekuasaan Politik Dalam Al-Qur`an. Jakarta : PT RajaGrafindo Persada

Sofyan, Ayi. Etika Politik Islam. Cet. I; Bandung : Pustaka Setia. 2012.

T.M. Hasbi Ash-Shiddieqy, Ilmu Kenegaraan dalam Fiqih Islam. Cet. II; Jakarta: Bulan Bintang, 1991.

Tim Penyusun, Ensiklopedi Nasional Indonesia, Jilid 16. Cet. I; Jakarta: Cipta Adi Pustaka, 1991.

Undang Hidayat. 2014. Politik Hukum Islam Dalam Sistem Hukum Tata Negara Republik Islam Iran. Jurnal Asy-Syari'ah Vol.16, No. 2, (https://journal.uinsgd.ac.id, diakses 20 November 2018). 